\title{
The Logical Construction and Analysis of "Three New" in the State Governance in the New Era
}

\author{
Dong Yan, Yang Yanqin, and Hou Jiayao \\ School of Marxism for Xi'an University of Science and Technology \\ Xi'an, Shaanxi, 710054
}

\begin{abstract}
Since the 18th National Congress of the Communist Party of China, the Party Central Committee with Comrade Xi Jinping as the core has been bravely practicing, actively innovating and gradually forming the new concept, new thoughts and new strategies for state governance by emphasizing on the major issue of "what is state governance, and how to implement state governance". The "three-new": the new concept, new thoughts and new strategies of $\mathrm{Xi}$ Jinping for state governance refers to an integral and synergic concept, and it has scientific and rigorous logic construction and internal connection, rather than the random matching of three individual concepts. The logic construction focus of the "three-new" along with the structure optimization and functional positioning for state governance can jointly form an integral theory with distinct layer and rich connotation, and it is a practical example for the persistence and development of the localization of Marxism in China.
\end{abstract}

Keywords-State governance; New concept; New thoughts; New strategies and logic construction

\section{INTRODUCTION}

State governance is related to the vicissitude changes and fortune of the state, and this is a significant problem emphasized and concerned by the ruling party and government of all countries worldwide [1]. The compliance concept for state governance is the main opinions and overall perspective of the ruling party for the theme of "what's the objective of state governance, and which kind of mode and status should we adopt for state governance", and it involves the comprehensive reflection of basic altitude, standpoint and development direction. The new concept, new thoughts and new strategies involved in state governance can be jointly called as "threenew", and it is an overall concept put forward by the Party Central Committee based on making an overall planning for economic social development, grasping the overall situation at home and abroad, and promoting the overall objective of the great cause of the revival of nationhood, these three have overall logic construction and closed internal connection, and can highlight the integrity, synergy and systematicness of the theory of state governance.

\section{REGULATIONS ABOUT THE INTERNAL LOGIC OF “THREE-NEW" FOR STATE GOVERNANCE}

"Three-new" proposition is the internal integration for the purpose of state governance, and these three have closed and systematic internal logic. The new concept of state governance that takes people as the core value, the assumption as political responsibilities, and the development as the first priority is the development guidance and emphasis direction; the new thought of state governance that takes the persistence and development of socialism with Chinese characteristics as the theme and the overall layout of innovation theory in various fields as the support is the thought guidance and essential objective; the new strategy of state governance that takes Chinese Dream as the strategic objective, "four-comprehensive" as the strategic layout, and the national safety and army strengthening as the strategic guarantee is the action program and practical guarantee for the aforementioned two actions.

\section{A. New thought of state governance: development guidance and emphasis direction}

Concept, i.e., idea and faith or rational concept, and it refers to the rational concept, and thought activities generated by the subject itself. Concept is the guidance for action, the pointer for managing the overall situation, the direction and long term, and also the generalization and simplification of development guidance and emphasis direction. Xi Jinping said that: "my concept for governance can be summarized as follows: serving the people, and taking the due responsibilities of the government." The new concept of state governance advocates active innovation; emphasizes on overall coordination; advocates sustainability, green development; deeply cultivates diversity and openness, and promotes communication and sharing. The new concept for governing the state and handling with affairs can be mainly reflected from several points below: the first one is legal construction, i.e., constructing legal China, adhering to maintaining the authority of constitution, and the immediate rights and interests of people. The second one is fairness and justice; in the new era, there is no doubt that the key problem that shall be mainly solved and explored for the entire system construction is to handle the right issues of state, society and citizens, and the active and valid maintenance of social justice and fairness has become the important measures to coordinate the conflicts of these three. The third one is judicial fairness, British Philosopher Bacon said that: "one unfair judgment can cause bad consequences that can even 
exceed ten times of crime." Since crime is a disregard of law, it is just like the pollution of water current; unfair judgment can damage laws, it is just like the pollution of water source. The Party Central Committee pointed out that, the promotion of thought incorruption construction considering party conduct as well as more effective anti-corruption struggle can never separate from the practical guarantee of judicial fairness, in order to get new achievements [2].

\section{B. New thought of state governance: thought command and essential guideline}

New thought has a position and role of thought guidance and essential guideline in state governance. The new thought in "three-new" emphasizes on the governing system and the modernization of governance capacity, and the practice and implementation of these two can be specifically reflected in the formation and construction of anti-corruption system, the law construction maintenance, social governance and stability maintenance, the optimization and upgrading of management service and other aspects. Firstly, it is requested to reinforce the construction of anti-corruption system, and normalize right operation. The solution of anti-corruption shall rely on system and legal institution in the end, and the Party Central Committee has put forward and stipulated the persistence of adopting system for standardized construction, and let the people extensively supervise rights, made the government right operate transparently, defined responsibilities and authorizes, and realized the reasonable operation of rights. Secondly, it is to reinforce legal construction, actively realize the scientization and modernization of governance capacity. As the basic mode and guarantee measures for state governance, the acceleration and continuous promotion of legal construction have a decisive significance in law-based governance, the promotion of national governance system and governance capacity [3]. Thirdly, it is to promote social governance reform, and the negotiation orientation, democratization and inclusiveness of social governance. "In an era that emphasizes and advocates diversity, and respects difference and innovation, consultative democracy opens a new journey for humans to develop and explore democratic ideal" [4]. The new thought for state governance is to emphasize on close cooperation of interaction and relevance considering the self-governance of government, the social adjustment and democratic autonomy on one hand, and on the other hand, it emphasizes on ensuring the promotion of governance efficiency, and adopting soft mode to implement the valid governance of the society. Fourthly, it is to reinforce the management service, and promote the urban and rural management service integration. The Party Central Committee puts forward that: it is requested to perfect and optimize system and mechanism construction, and ensure the formation of innovative workers and peasants urban and rural relationships that can realize the promotion of agriculture through industry, the promotion of villages through cities, the mutual benefit of workers and peasants, and the urban and rural integration [5].

\section{The new strategies for state governance: action agenda and practical guarantee}

Any plan and policy can only have actual significance after being converted to actual implementation action and the guidance of new concept and new thoughts must be converted to new strategies for implementation. New strategies are the basis and specific implementation of new concept and new thoughts, and also the action guideline and practical guarantee for state governance. New strategies refer to implementing new concept and new thoughts from strategic objective, strategic steps, strategic key points and strategic measures, etc. The strategic objective is to realize the Chinese dream of bringing about a great rejuvenation of Chinese nation, and finally realize national prosperity, national rejuvenation and people's happiness. The strategic steps refer to "two one-hundred year" objective, which shall be ensured to be implemented by steps. The strategic key points refer to the overall layout of "four comprehensive" strategies. The strategic key points refer to strategic tasks with decisive significance and crucial emphasis field, and it is an important board and key part related to whether the overall objective can be realized and completed. These four aspects have comprehensively and clearly drawn up the four big strategic key points for state governance. The strategic measures refer to the overall layout plan of "five-inone", and it shall be specifically implemented in economic, political, cultural, social and ecological strategic measures.

\section{The OVERALl LOGIC DEMAND OF “THREE NEW” FOR STATE GOVERNANCE}

The logic main line for the localization of Marxism in China runs through the entire "three-new" theory, and the "three-new" has basically the same history, reality, theory and political basis, and these three involve the stability of reform development, the national defense and internal affairs diplomacy, governing the party, the country and the army and other basic categories.

\section{A. The main line of thoughts running through "three new" and the value objective are the same}

The "three-new" theory for state governance always adheres to developing the main thought line of socialism with Chinese characteristics and the localization of Marxism in China, and under the new era background and social environment, it can pointedly answer the new situation and new problems faced in the process of state governance during the new era. "Three-new" adheres to the essence of MarxismLeninism, Mao Zedong Thought, and the Theoretical System of Socialism with Chinese Characteristics, adheres and applies the essential opinions and fundamental method of these three, and meanwhile, on this basis, innovates in combination with the actual demands of the new era. On one hand, "three-new" follows and runs through the essential opinions and thinking mode of Marxism, and can provide the fundamental direction and reasonable guidance for scientifically and reasonably using philosophy standpoint thinking mode of Marxism to analyze and effectively solve problems. On the other hand, "three-new" adheres to the primary objective and interest orientation of taking people as the direct subject of values and interests, and placing the interests of people in the first place, and the biggest 
starting point and ultimate objective of "three-new" refer to "letting people live better, letting people become the biggest beneficiary subject of national development and social progress". Speaking of the essence, the contents of "three-new" refer to the reasonable new example persisted by the Party Central Committee taking General Secretary Xi Jinping as the core, with the combination of Marxism and the actual conditions of China during the contemporary era.

\section{B. The generation foundation for "three-new" is the same with the formation basis}

"Three-new" is driven by the objective of realizing the Chinese dream of bringing about a great rejuvenation of Chinese nation and increasing the happiness of people, and takes the realization of "two one-hundred year" struggling objective as the roadmap and schedule. The "three-new" thought for state governance has four big bases; the excellent traditional profound culture in China is the historical basis for the "three-new" for state governance; the accurate judgment and experience summary of world conditions, party conditions and national conditions are the realistic base for the "threenew" for state governance; the persistence and development of socialism with Chinese characteristics are the political basis for the "three-new" for state governance; the scientific integration and expansion leap of Mao Zedong Thought and the socialist theory system with Chinese characteristics afterwards are the theoretical basis. The "three-new" is put forward on the basis of scientifically judging the world conditions, the party conditions and national conditions, and is the newest theoretical achievement for the localization of Marxism in China, and it is a new promotion and development on the basis of previous state governance related theoretical system integration.

\section{The basic category involved in "three-new" is the same with the radiation territory}

Since the18th National Congress of the Communist Party of China, General Secretary Xi has delivered lots of important speeches, comprehensively and systematically elaborated the basic category for state governance under the new trend and the new era as well as the different regions it can radiate. Firstly, the reform development is table, and in the reform process, it is requested to pay attention to the integrity, synergy and systematicness of reform. Optimize development, clearly emphasize that the current development of our country is still under the strategic opportunity period, and it is requested to keep continuously high-efficient development, and strengthen stability; secondly, it is the national defense and internal affairs diplomacy, the Party Central Committee advocates "handling well the affairs in China", when it comes to state governance, promotes the construction of economy and it shall be mutually integrated with national defense related construction in development, and it is requested to gradually increase the development of military and civilian integrated field to the overall strategic level of the state. Meanwhile, it is requested to fulfill the neighboring diplomacy concept of kindness, sincerity, benefit and tolerance; thirdly, it is party governance, state governance and army governance, taking style construction as the cutting point, and closely grasping the main line of comprehensively strengthening party governance. Meanwhile, it is requested to establish legal thinking mode, and build a qualified, high-efficient and elite people's army.

\section{COMmon LOGIC Misunderstandings ABOUT THE "THREE-NEW" FOR STATE GOVERNANCE}

The molding of "three-new" concept for state governance is based on the long-term consideration in time and the overall plan in space and in the process of understanding the "threenew" concept for state governance, there are different degrees of thought restrictions and logic misunderstandings. The common misunderstandings are as follows: firstly, it is to place the concept of state governance and the "four-comprehensive" at an equal position. "Four-comprehensive" strategic layout is the overall strategy and overall route for state governance, and the two are the relation of whole and part. Secondly, it is to simply regard the new thought for state governance as the same with the new normal thoughts. New normal specially refers to the new normal of economy, and $\mathrm{Xi}$ Jinping pointed out that new normal is mainly and intensively reflected in the economic field, and cannot be misused. Thirdly, it is to directly regard state governance as the same with the five development concept. The subject for five development concepts is the entire society, and the subject for state governance is obviously the ruling party, and it is the extension and specific elaboration conducted through closing emphasizing on the centralized theme of "ruling". Fourthly, it is to place the new concept, new thoughts and new strategies for state governance at an equally important position with "series of important speeches". The 18th Sixth Plenary Session of the party clearly mentioned that: "deeply implementing the series of important speech spirits of General Secretary Xi Jinpin and the new concept, new thoughts and new strategies for state governance;"[6], and it placed the two in the same session, and jointly put forward that, the obvious difference was that, the former "series of important speech" had successive part to a large extent and also innovative contents, but as the name implies, the latter "new concept, new thought and new strategy" refer to the new strategic thoughts and concept formed on the basis of the background characteristics of the new era and corresponded to the basis.

\section{SUMMARY}

The concept of "three-new" for governing the state and handling with the policies was put forward in making an overall plan for economic social development and the overall situations at home and abroad, and these three can constitute an overall theoretical mode with distinct gradation, and rich connotation, and can also highlight the integral and systematic thinking logic. The "three-new" for governing the state and handling with the policies is the scientific guidance for deepening reform and opening-up, accelerating and continuously promoting socialism modernization under the new era, and also a successful example for adhering to developing localization of Marxism in China; besides, it has opened a new situation for the development of socialism with Chinese characteristics. 


\section{ACKNOWLEDGMENT}

Dong Yan, female, born at Danfeng of Shaanxi in March, 1970, and the Master of the Education of Marxist Theory and Education in Ideology and Politics, the Teacher, Professor and Postgraduate Tutor of School of Marxism for Xi'an University of Science and Technology.

Yang Yanqin, female, born at Lanzhou of Gansu in July, 1993, the Master Degree Candidate of Xi'an University of Science and Technology, and her research direction is Marxist Theory (E-mail Address: 1425482490@qq.com Contact No.: $15769415469 / 15529427112)$.

\section{REFERENCES}

[1] Chen Baosheng. Providing System Support for the Lasting Political Stability of the State-Progress and Effect for Promoting State Governance System and Governance Capacity since the 18th National Congress of the Communist Party of China [J]. Guangming Daily, 2016.5.25.

[2] Cheng Guohua. New Concept, New Practice and New Direction for Governing the State and Handling with the Policies since the 18th National Congress of the Communist Party of China [J], Socialism Study, 2016.6.32.

[3] Ying Songnian. Accelerating Legal Construction, and Promoting the State Governance System and Governance Capacity Modernization [J]. China Legal Science, 2014 (6).

[4] Chen Jiagang. Deliberative Democracy and State Governance [M]. Beijing, Central Compilation \& Translation Press, 2014 Introduction Theory, Page 5.

[5] Li Zengyuan. Separation and Integration: Converting the Integration of Peasant Flow in the Society with the Community-Empirical Investigation Based on Wenzhou [J] Doctoral Thesis of Central China Normal University, 2013.

[6] CPC 18th Sixth Plenary Session was held in Beijing [N] People's Daily, $2016,10.28$ (1). 